\title{
Indigenous fodder trees can increase grazing accessibility for landless and mobile pastoralists in northern Pakistan
}

\author{
Inam-ur-Rahim ${ }^{1 *}$, Daniel Maselli, ${ }^{1,2}$, Henri Rueff ${ }^{3}$ and Urs Wiesmann ${ }^{3}$
}

\author{
* Correspondence: inam \\ rahim@ucentralasia.org \\ ${ }^{1}$ University of Central Asia, 138-138 \\ A Toktogul Street, 720001 Bishkek, \\ Kyrgyz Republic \\ Full list of author information is \\ available at the end of the article
}

\begin{abstract}
Degraded hillsides in Northern Pakistan are rehabilitated through social forestry campaigns using fast growing exotic trees. These plantations on former scrublands curtail access by livestock owned by landless pastoralists and create social tension. This study proposes an alternative strategy of planting indigenous fodder trees and shrubs that are well-suited to the local socio-ecological characteristics and can benefit all social segments. The choice of fodder tree species, their nutritional value and distribution within the complex socio-ecological system is explained. This study also explores the suitability of these trees at different elevations, sites and transhumant routes. Providing mobile herders with adequate fodder trees could relax social tensions and complement food security.
\end{abstract}

Keywords: fodder trees feed scarcity, nutritional value, landless transhumants, trekking routes

\section{Introduction}

Forestry agencies in many regions of the world tend to evict pastoralists when planting exotic trees on large swaths of grazing land (Rueff et al. 2004). Tension between foresters and pastoralists is further increased because the former favours fast growing, drought resistant species over fodder trees, which are preferred by the pastoralists (Rueff et al. 2008). Joint Forest Management as well as other management approaches have promoted alternative forest management ideas to solve conflicts between foresters and pastoralists. One approach consisted of including local communities in the management process of forests, and anticipating the needs of these communities when selecting species to be planted (Rueff et al. 2008).

Subsistence famers usually include trees as an output product of their farm, whether it is for wood, shade, soil conservation, or fodder (Zomer et al. 2009). Herders rely on fodder trees in the dry season because the foliage retains sufficient crude protein, minerals and energy due to the deep root systems of these species (Speedy and Pugliese 1992; Paterson et al. 1998; Upreti and Shresta 2006). The landless mobile herders described in this study (see methodology for further description) mainly depend on naturally grown fodder trees and shrubs. In arid and semi arid zones like those of the Sahel, tree feed resources growing near villages, roadsides and communal lands contribute up to $80 \%$ of the protein during the dry spells (Speedy and Pugliese 1992). (c) 2011 ur-Rahim et al; licensee Springer. This is an Open Access article distributed under the terms of the Creative Commons Attribution License (http://creativecommons.org/licenses/by/2.0), which permits unrestricted use, distribution, and reproduction in any medium, provided the original work is properly cited. 
Having access to fodder plants and being able to use them also depends on social status. In Pakistan, this relates to landowner relative to landless mobile herders and on the elevation distribution of fodder trees and shrubs. In Northern Pakistan, collapsing traditional institutions that formerly managed communal hillsides, and the inability of the new formal institutions to provide alternatives, led to severe deforestation and hillside degradation (Rahim and Viaro 2002). To address this issue, social forestry initiatives emerged in the early 1980's and lasted until the end of the century (Leede et al. 1999). To rehabilitate the overused mountain slopes, tree species planted for social forestry projects included Eucalyptus camaldulensis, Pinus roxburghii and Robinia pseudoacacia. These species were more applicable to watershed rehabilitation functions than to meet the needs of people (Rahim and Viaro 2002). Landowners either evicted herders or made hillsides inaccessible to them. From the landowners' perspective, this was a necessary move to protect any planted trees (Leede et al. 1999). Between 1980 and 1999, the plantation campaigns reduced the possible access to free grazing areas for mobile herders by $54.5 \%$ and reduced access to leased winter grazing areas by $75.9 \%$ (Leede et al. 1999).

Forest cover with exotic species not only replaced the traditional silvo-pastoral forages (Rahim and Viaro 2002) but was also perceived as a negative development by nomadic grazers, despite an increase in grass and tree cover on the protected sites (Leede et al. 1999). As a result, the average herd size of the landless pastoralist decreased from 340 to 140 goats and sheep. About 25\% of the landless mobile sheep and goat herders sold all their animals and ended up as cropping labour or finding daily wage labour elsewhere (Leede et al. 1999). The net result was that the absent landlords, having ownership rights but no direct dependence on hillsides, were rewarded by reaping the benefits through sale of fuel from wood and could increase their control over the hillside, whereas the landless herders, dependent on hillsides for their livelihoods, were left to bear the cost (Rahim and Viaro 2002).

With plantations of indigenous fodder trees in the hillsides, the interests of both landowners (tenure, rent) and landless herders (availability of fodder from trees and shrubs) can be achieved. With the incentive of increased feed availability from fodder trees and shrubs, the landless herders will be more likely to temporarily restrict part of their herd (especially goats) from the hillside to allow establishment of the forest cover.

Although many development programmes in the Himalayan Hindu-Kush Mountains plant fodder trees, they ignore indigenous species and introduce exotic species (Komwihangilo et al. 1995). This study identifies key fodder trees and shrubs, their nutritional value and distribution at different elevations. Further, this study assesses the utilization and access by different social groups to identify trees and shrubs suited to different locations and that can meet the needs of herders in terms of forage for their animals.

\section{Study area}

The study was conducted in Buner and Swat in the Trans-Himalayan sub-humid, subtropical to semi-arid temperate zone, occupying part of the Malakand Division. Physically, the valley lies in the Hindu-Kush mountain ranges, but climatically it resembles the bordering Himalayan mountain range. The study area was located on the right bank of the Indus River, between 34.29 to 35.30 degrees north and 72.39 to 72.34 degrees west. Narrow valleys with gentle to steep hill slopes (average 33\% slope) characterize the area. It extends $100 \mathrm{~km}$ from the foothills of Chagharzai valley in 
Buner (up to $800 \mathrm{~m}$ altitude) in the south to Kalam in Swat Kohistan in the northnortheast (greater than $2000 \mathrm{~m}$ altitude) (see Figure 1). The annual precipitation varies from 600 to $1000 \mathrm{~mm}$ and occurs mostly during summer (mid-July to mid-September) and spring (February to May). Transhumant herders come to Buner foothills during winter and proceed to upland pastures near Kalam during summer. At upper elevations, a mono-seasonal cropping pattern dominates, particularly on northern slopes, whereas at middle and lower elevations the cropping is bi-seasonal. The Sino-Japanese vegetation region extends through Nepal and Kashmir and occupies the entire valley (Ahmad and Sirajuddin 1996). The extremely rich and diverse vegetation is

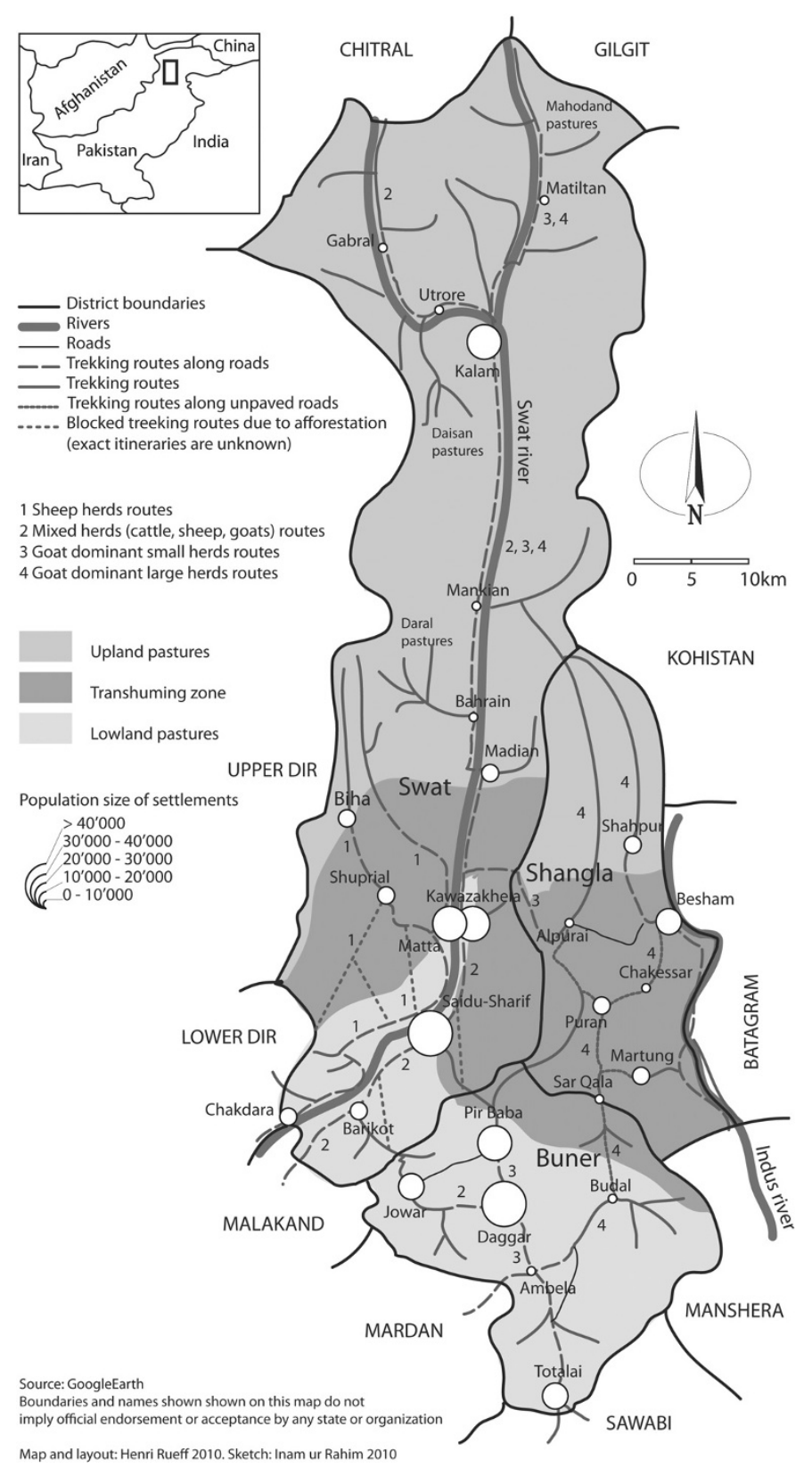

Figure 1 Transhumance routes, pasture occupation and livestock species in the Swat and Buner districts, Khyber Pukhtunkhwa, Pakistan. 
characterized by the evergreen pine-oak with a transition to scrub, dominated by the large pinnate leaved families (Boufford and Ohba 1998).

All households possess livestock, including both landowners and tenants of the lower elevation sedentary zones. The landowner herds contain 2 to 5 buffaloes and a pair of draught bulls. The tenant herd may contain 4 to 7 buffaloes or cows and young bovine stock, a pair of draught bulls, 1 to 2 equines and 8 to 15 goats or sheep. The nomadic or transhumant pastoral flocks may contain 100 to 150 goats and sheep, a few cattle to meet the milk requirements of the family ( 2 to 4 cows), and a few equines for load carrying and riding ( 2 to 4 mules, donkeys or horses) (Agriculture Census Organization 2006). Household land holdings are typically small and rarely exceed 3 hectares, including private grazing land.

Agriculture is predominantly oriented towards mixed farming in which livestock plays a crucial role. At lower elevations a sedentary system predominates, whereas semi-migratory and migratory systems predominate at higher elevations. Typical of most arid and semi-arid mountain regions, transhumant pastoralists are among the poorest and most powerless communities. This trend is compounded on the one hand by the increased frequency of climate extremes and on the other hand by economic pressures on farmers through high input farming and unsustainable farming practices which further damage mountain slopes (FAO 2002).

\section{Background on land tenure}

The territory used by landless transhumant herders in the Malakand region of Northern Pakistan is divided into three parts: (1) the lowlands below $1250 \mathrm{~m}$ towards the south, (2) the intermediary zones from 1250 to $3000 \mathrm{~m}$, and (3) the uplands above $3000 \mathrm{~m}$ towards the north. The lowland and a large portion of the intermediary zones are mostly occupied by the Yousafzai Afghans, while the uplands and a small portion of the intermediary zone are occupied by the Kohistani Dards. Lowlands and intermediary zones have multi-seasonal irrigated cropping and mono- and bi-seasonal rain-fed agriculture, while the only type of agriculture in the uplands is mono-seasonal and irrigated. The irrigated lands are used by landowners while the rain-fed and grazing lands are rented out. Pastures are rented under a communal regime, while cropping is on an individual tenancy basis (Rahim and Viaro 2002). Herders usually assign a contractor to negotiate the rental contract with landowners on a yearly basis. A sub-let is then arranged for each herder individually on a per-animal basis. As the number of animal increases, the cost per animal decreases.

About 40 years ago, before major land reforms and land use changes were implemented, agriculturalists and pastoralists benefited each other. The six weeks transhumance journey of landless pastoralists was in phase with staple harvesting of agriculturalists. Thus, while herders progressed towards their upland pastures in early summer, their animals were stubble fed on freshly harvested fields while the animals would leave their manure fertilizing the land. Agriculturalists would reward herders with staple flour. The same happened in autumn while transiting back to the lowlands. This complementary relationship ceased when staple cultivation was replaced with commercial vegetable and orchards, and when surrounding hill slopes were closed for afforestation programmes. 
After the merger of the independent princely states of Swat, Dir and Chitral into Pakistan, new regulatory mechanisms were introduced. The forests, scrubs and upland pastures were declared state property, though only of de jure nature since previous communal arrangements continued to persist. Furthermore, the land reform act which was introduced in 1974 under Bhutto's regime (1971-78) prevented tenants' eviction, which further complicated the overall tenure situation. Some tenants refused to pay rents, which led to a series of armed conflicts with the landowners. As a result of tenure disputes and the loosening control on hillside resources, the subsequent 10 years experienced a classical "Tragedy of the Commons" (Hardin, 1968) situation, whereby entire forests on lowland hillsides were chopped down and shrubs uprooted by poor villagers. The sheep and goat herders were not among such claimants because of their mobile livelihood, but they were among the main losers, as they depended on the vegetation of these hillsides for grazing and browsing. Such events compelled the landowners to privatize hillsides and to sell them to the occupants. Still, the Yousafzai held most of the lowland. In the upland the Kohistani Dard face no such tenure disputes.

To rehabilitate the degraded hillsides, different "Social Forestry" and "Watershed Management" projects started in the region in 1985. The arrangement was that the landowners would let foresters plant on their land and manage plantations. After five years, the plantation would be handed to the landowners. The success of these afforestation projects required that transhumant herders be excluded (Leede et al. 1999). The communal landowners losing grip on their hillsides saw the foresters' offer as an opportunity to expel the tenants and have control over their land. The plantations in themselves did not interest landowners too much, even if they could get an income from the fuelwood after the 5 year period.

Afforestation campaigns further reduced the space for grazing and browsing for the landless herders' livestock and reduced significantly the flock sizes. A case study (Leede et al. 1999) in six villages in lowlands in the region revealed that the total grazing land was reduced by $55 \%$ because of afforestation. Consequently, the average flock size of the transhumant herders there reduced from about 340 to 200 sheep and goats per herd. Many of the traditional trekking routes of transhumant herders were blocked by the afforestation programs, obliging herders to use roads and to have two or three additional shepherds to protect animals from the traffic. Furthermore, a sizable proportion of the herders were obliged to leave the profession and ended up as daily wage labourers. Clearly afforestation programs have contributed to marginalizing herders.

\section{Methodology}

\section{Identification of consumable forages and their patterns of use}

A questionnaire containing two parts was prepared to interview farmers at lower, middle and upper elevations of the study area. Thirty-nine traditional male common houses (locally known as Hujra that represent 40 to 100 households in a village ward) in different villages were visited to interview the landowners and tenants. In total, 195 individuals from each social group (landowners, tenants and transhumant livestock herders) were interviewed. The primary male household heads among landowners and tenants identified the local expert for identification of trees and shrubs. The 
questionnaire was pre-tested on nine respondents, three at each elevation, before proceeding with the data collection.

The first part of the questionnaire was related to the identification of different fodder trees and shrubs species, season of availability and use, main user group (livestock species to be fed) and trends in its availability. Farmers and nomads were asked for the tree and shrub names in their local language (Pushtu), and the sample was collected and preserved for subsequent botanical identification. Initially all the available forage species were identified with local names prior to entering them into the questionnaire. The second part of the questionnaire referred to feeding patterns of different livestock species during different seasons.

\section{Sampling of trees and shrubs}

The samples of all identified fodder trees and shrub species were collected and preserved in the form of a catalogue. The catalogue was used for botanical identification in Pakistan, at the Department of Botany, Islamia College, University of Peshawar, and at the Pakistan Forest Institute in Peshawar. Twenty of the most commonly used and available fodder trees and ten most commonly used fodder shrubs at different elevations and slopes within the study area, and consumed by different categories of livestock, were selected for further evaluation. The samples were collected by farmers during the harvest season. The leaf samples were randomly collected from selected villages. A portion of the foliage consumed by livestock, as identified by the key respondent, was harvested for chemical analysis, digestibility and palatability experiments.

For each of the tree and shrub fodder specimens, $15 \mathrm{~kg}$ samples were collected, airdried and transported for nutritional evaluation and palatability trials. The air-dried samples were chopped 2 to $3 \mathrm{~cm}$ in length and stored in polythene bags. From each sample, $4 \mathrm{~kg}$ of air-dried material was stored locally for palatability testing and $2 \mathrm{~kg}$ of that material was saved for further analysis and in vitro digestibility studies. The remaining material was mixed and used to feed the experimental animals (for palatability and digestibility trials) during experiment and adjustment periods.

\section{Nutritional evaluation of range forages}

To analyze forages, moisture content is important, as animal nutrient requirements are expressed on a dry matter basis (Shenk and Barnes 1985). Protein is necessary for the production of milk, muscle, wool and hair and to replace proteins lost during maintenance (Minson 1990). Animals are not able to extract all nutrients present in feeds. The actual value of ingested nutrients depends on digestibility, since undigested nutrients are not utilized by the body. Digestibility is usually the first measure of nutritive value and is used as an index of the feeding value of herbage (Minson 1987). In vitro dry matter digestibility (IVDMD) is considered to be a good predictor of in vivo digestibility (Marten and Barnes 1980). The energy value of a quantity of forage varies as a function of its digestibility and can be derived from the digestibility of the feed (Huston and Pinchak 1993).

The air-dried forage samples collected during the research were further dried in a forced drought oven at $60^{\circ} \mathrm{C}$. These samples were then analyzed for chemical constituents of forages, such as Dry Matter (DM) and Nitrogen (AOAC 1990). For IVDMD, 
oven dried samples were ground and incubated at $37 \pm 1^{\circ} \mathrm{C}$ for 48 hours between $\mathrm{pH}$ $6.7-7.0 \mathrm{in}$ an all glass system using $45 \mathrm{ml}$ of inoculum. The inoculum consisted of 36 $\mathrm{ml} \mathrm{McDougal's} \mathrm{artificial} \mathrm{saliva} \mathrm{and} 9.0 \mathrm{ml}$ strained fresh rumen liquor from grass fed sheep. After incubation and centrifugation the residue was treated for 48 hours with pepsin in weak acid ( $\mathrm{pH}$ 2.0). The final residue was a measure of in vivo digestibility and consisted of undigested plant cell walls and bacterial debris (Tilley and Terry 1963).

The palatability and digestibility of forage determine the amount of feed that an animal will consume and convert into products (Etgen and Reaves 1978). Ruminants attempt to select a diet that promotes high level of feed intake (Cooper et al. 1996). Potential Intake Rate (PIR) is thus the best indicator of palatability (Kenney and Black 1984).

To estimate PIR, four mature local sheep, 2 to 3 years old with an average body weight of $40 \mathrm{~kg}$, were purchased from the local livestock market. These sheep were drenched for internal parasites prior to their use in the experiments. Experiments for palatability measurements were conducted at the Civil Veterinary Dispensary, Deewana Baba, in the Buner District of the Malakand Division. During preliminary periods, each animal was fed about $800 \mathrm{~g} /$ day. The diet consisted of $80 \%$ mixed grass hay and $20 \%$ concentrate mixture. Feed provided during the preliminary period contained $10 \%$ crude protein $(\mathrm{CP})$ and $2.0 \mathrm{Mcal} / \mathrm{kg}$ of Metabolizable Energy (ME). Prior to the experiment, the sheep were adapted to the dried tree and shrub leaves, and trained to consume the samples by repeatedly offering the test samples to them. It took about five weeks to accustom the sheep to the fodder tree and shrub leaves and the experimental procedure before any measurements were taken. The PIR for different forages was determined through the procedure adopted by Atiq-ur-Rehman Atiq-ur-Rehman (1995). Each forage species was offered to the sheep for a set of comparisons consisting of four consecutive periods of one minute each at ten minute intervals. Sheep were offered forages in suitable plastic containers to ensure that some forage was left over after one minute of feed consumption.

\section{Statistical Analysis}

The qualitative data on availability and use pattern were summarized in tables, whereas the mean of eight sub-samples analysed for each fodder tree and fodder shrub for DM, CP and IVDMD were calculated to estimate nutritional value. The data for PIR was analyzed using analysis of variance in a group balanced block design (Gomez and Gomez 1984) and the means were compared by least significant difference (Steel and Torrie 1982).

\section{Results and discussions}

\section{Seasonal variation in use of fodder from trees and shrubs}

Different fodder trees and shrubs contribute to the ration of livestock during different seasons. The farmers in the study area identify six seasons based on a local feeding/ cropping calendar. In general, there are two seasons of scarce feed resources reported in the study area: the dry summer season covering a period from early June to midJuly, and winter from early December to the end of February. Fodder trees contribute to livestock rations especially during these scarce seasons. As elevation increase, the 
length of the dry summer scarce season reduces. Conversely, the winter scarce season is longer at higher elevations and shorter at lower elevations. The use of some fodder trees extends beyond the typical scarce season. Some of the shrubs are being freely browsed throughout the entire year, whereas others are lopped and provide foliage for intensive feeding during the scarce seasons. Table 1 summarizes the availability and use of fodder trees and shrubs during different seasons.

In addition to tree and shrub leaves, sheep and goats consume the seed pods of Robinia pseudoacacia, Acacia modesta and Acacia nilotica in autumn. Diospyros lotus is a fruit tree. However, the leaves are lopped during years of extended summer drought at the expense of fruit production. The leaves of Aesculus indica are lopped during autumn and dried for feeding during winter. Dodonaea viscosa is a lowland unpalatable shrub. However, the transhumant herders force their sheep and goats to browse these leaves as they are believed to have a de-worming effect. Cotoneaster nummularia and Impatiens bicolor are not only browsed, but also lopped by transhumant herders for feeding the kids and lambs at the barn when the dams are away grazing on pastures.

\section{Availability and patterns of use of fodder trees and shrubs at different elevations}

Understanding the distribution of fodder trees according to elevation provides important information on how tree planting programmes should be organized to benefit herders (table 2). Also, the species of fodder trees and shrubs used vary by livestock species, age group, and production level. Betula utilis trees are available at very high elevations, mainly in the upland pastures, where no other tree species can grow. Corylus avellana trees are available in the subalpine forest zone. The leaves of Betula utilis are pruned specifically to feed weak calves that cannot thrive well in the uplands. The leaves of Corylus avellana are pruned and fed fresh to young calves, kids, and dams just after parturition. Salix tetrasperma is common in the riparian zones of torrent streams and rivers at all elevations. Its leaves are pruned for feeding all categories of livestock, and mainly for herds of landless tenants and herders. During periods of scarcity, the leaves are lopped by landowners as well. However, after the period of scarcity, the marginal social segments, particularly the sedentary tenants, still utilize the leaves of this evergreen tree for feeding their goats and calves. Aesculus indica is available at all elevations and is mainly used for shading at lower and middle elevations. At high elevations, where the period of scarcity is longer, landowners regularly lop leaves of this tree in late summer and autumn. The leaves are stored alongside hay and used to feed all categories of livestock in winter. The leaves of Quercus incana and Quercus dilatata at higher elevations remain green throughout the winter and are the only source of green foliage for wintering livestock. The leaves of Quercus incana are used to feed all categories of animal, whereas the leaves of Quercus dilatata are fed only to non-milking and non-pregnant animals because of a belief that it would reduce milk production and induce abortion in pregnant animals. Morus alba is mainly a shade tree available at strategic locations in villages, such as inside the courtyards of houses and Hujras ${ }^{\mathrm{a}}$. It is also planted at the junctions of croplands to provide shade for those working in the field in summer time. However, after the early summer harvest and at the end of the ploughing season, the leaves are lopped for feeding livestock. Morus nigra is less appreciated because of its black coloured fruit that makes the 
Table 1 availability and use of fodder trees and shrubs during each season

\begin{tabular}{|c|c|c|c|c|c|c|c|}
\hline \multirow[t]{2}{*}{ Fodder plant } & \multirow{2}{*}{$\begin{array}{l}\text { Local name in } \\
\text { Pushtu }\end{array}$} & \multicolumn{6}{|c|}{ Type of fodder use during each season } \\
\hline & & Spring & $\begin{array}{c}\text { Dry } \\
\text { summer }\end{array}$ & $\begin{array}{c}\text { Wet } \\
\text { summer }\end{array}$ & $\begin{array}{c}\text { Early } \\
\text { autumn }\end{array}$ & $\begin{array}{l}\text { Late } \\
\text { autumn }\end{array}$ & Winter \\
\hline \multicolumn{8}{|l|}{ Trees } \\
\hline Aesculus indica & Jawaz & $\mathrm{D}$ & & & & & D \\
\hline Quercus incana & Spin Banj & $\mathrm{F}$ & & & & & $\mathrm{F}$ \\
\hline Olea cuspidate & Khona & $\mathrm{F}$ & & & & & $\mathrm{F}$ \\
\hline Grewia oppositifolia & Pastaoonay & $\mathrm{F}$ & & & & & $\mathrm{F}$ \\
\hline Ficus sarmentosa & Batinzer & $\mathrm{F}$ & & & & & $\mathrm{F}$ \\
\hline Zizyphus jujuba & Baira & $\mathrm{F}$ & & & & & $\mathrm{F}$ \\
\hline Acacia modesta & Keeker & $\mathrm{F}$ & & & & P & $\mathrm{F}$ \\
\hline Acacia nilotica & Palousa & $\mathrm{F}$ & & & & $P$ & $\mathrm{~F}$ \\
\hline Quercus dilatata & Tour Banj & $\mathrm{F}$ & $\mathrm{F}$ & & & & $\mathrm{F}$ \\
\hline $\begin{array}{l}\text { Robinia } \\
\text { pseudoacacia }\end{array}$ & Angrezi Keekar & $\mathrm{F}$ & $\mathrm{F}$ & & & P & \\
\hline Betula utilis & Braj & & $\mathrm{F}$ & $\mathrm{F}$ & & & \\
\hline Corylus avellana & Zangali badam & & $\mathrm{F}$ & $\mathrm{F}$ & & & \\
\hline Diospyros lotus & Tour Amluk & & $\mathrm{F}$ & $\mathrm{F}$ & & & \\
\hline Morus alba & Spin Toot & & $\mathrm{F}$ & $\mathrm{F}$ & & & \\
\hline Morus nigra & Tour Toot & & $\mathrm{F}$ & $\mathrm{F}$ & & & \\
\hline Ailanthus chinensis & Laintus & & $\mathrm{F}$ & $\mathrm{F}$ & & & \\
\hline Salix tetrasperma & Wala & & $\mathrm{F}$ & $\mathrm{F}$ & $\mathrm{F}$ & & \\
\hline Celtis australis & Tagha & & $\mathrm{F}$ & $\mathrm{F}$ & $F$ & & \\
\hline Celtis caucasica & Khangrho & & $\mathrm{F}$ & $\mathrm{F}$ & $\mathrm{F}$ & & \\
\hline Melia azedarach & Shandai & & & $\mathrm{F}$ & $F$ & & \\
\hline \multicolumn{8}{|l|}{ Shrubs } \\
\hline $\begin{array}{l}\text { Cotoneaster } \\
\text { nummularia }\end{array}$ & Mamanra & $\mathrm{F} / \mathrm{B}$ & & & & & $F / B$ \\
\hline Impatiens bicolor & Baikrhai & $\mathrm{F}$ & & & & & $\mathrm{F}$ \\
\hline Myrsine Africana & Marourhang & B & & & & $\mathrm{B}$ & B \\
\hline Anisomeles indica & Tour Panra & & & $B$ & B & & \\
\hline Dodonaea viscosa & Ghwarhaskey & & & & & & $B$ \\
\hline $\begin{array}{l}\text { Indigofera } \\
\text { heterantha }\end{array}$ & Gwaraija & & & B & B & & \\
\hline $\begin{array}{l}\text { Indigofera } \\
\text { gerardiana }\end{array}$ & Kainthai & & B & B & B & $\mathrm{B}$ & \\
\hline $\begin{array}{l}\text { Debregeasia } \\
\text { salicifolia }\end{array}$ & Ajlai & B & & B & B & B & B \\
\hline Artemisia maritima & Jaokay & B & & B & B & B & B \\
\hline
\end{tabular}

ground underneath the tree unsuitable for sitting once the fruit falls. It therefore grows only in the wild and particularly in more moist and deep soil areas.

Grewia oppositifolia, Zizyphus jujuba and Celtis australis are trees specifically planted at field boundaries to provide fodder during late autumn and winter (periods of fodder scarcity). They are considered very high value fodder and are provided to 
Table 2 tree and shrub species altitudinal distribution and use by livestock species and age group

\begin{tabular}{|c|c|c|c|c|c|c|c|c|c|c|}
\hline \multirow[t]{2}{*}{ Name of tree/Shrub } & \multicolumn{3}{|c|}{ Altitudinal zone } & \multicolumn{4}{|c|}{ Livestock species } & \multicolumn{3}{|c|}{ Type of livestock } \\
\hline & $L$ & $M$ & $\mathrm{H}$ & $S$ & G & C & B & $y$ & $a$ & $\mathrm{~m}$ \\
\hline \multicolumn{11}{|l|}{ Trees } \\
\hline Salix tetrasperma & $x$ & $x$ & $x$ & & & $x$ & $x$ & & $x$ & \\
\hline Robinia pseudoacacia & $x$ & $x$ & $x$ & $x$ & $x$ & & & $x$ & $x$ & $x$ \\
\hline Morus alba & $x$ & $x$ & & & & $x$ & $x$ & & & $x$ \\
\hline Ailanthus chinensis & $x$ & $x$ & & & & $x$ & $x$ & & & $x$ \\
\hline Celtis australis & $x$ & $x$ & & & & $x$ & $x$ & $x$ & $x$ & $x$ \\
\hline Morus nigra & $x$ & $x$ & & & $x$ & $x$ & & $x$ & $x$ & $x$ \\
\hline Aesculus indica & & $x$ & $x$ & & & $x$ & & & $x$ & \\
\hline Quercus incana & & $x$ & $x$ & & & $x$ & & & $x$ & \\
\hline Quercus dilatata & & $x$ & $x$ & & $x$ & $x$ & & & $x$ & \\
\hline Acacia modesta & $x$ & & & $x$ & $x$ & & & $x$ & $x$ & $x$ \\
\hline Acacia nilotica & $x$ & & & $x$ & $x$ & & & $x$ & $x$ & $x$ \\
\hline Olea cuspidata & $x$ & & & $x$ & $x$ & & & $x$ & & $x$ \\
\hline Zizyphus jujuba & $x$ & & & $x$ & $x$ & $x$ & $x$ & $x$ & & $x$ \\
\hline Grewia oppositifolia & $x$ & & & & & $x$ & $x$ & & & $x$ \\
\hline Diospyros lotus & & $x$ & & & $x$ & $x$ & & $x$ & $x$ & $x$ \\
\hline Celtis caucasica & & $x$ & & & $x$ & $x$ & & $x$ & $x$ & $x$ \\
\hline Ficus sarmentosa & & $x$ & & & $x$ & & & $x$ & $x$ & $x$ \\
\hline Melia azedarach & & $x$ & & $x$ & $x$ & $x$ & $x$ & & & \\
\hline Betula utilis & & & $x$ & & & $x$ & & $x$ & & \\
\hline Corylus avellana & & & $x$ & & & $x$ & & & & $x$ \\
\hline
\end{tabular}

\section{Shrubs}

\begin{tabular}{|c|c|c|c|c|c|c|c|c|c|c|}
\hline Dodonaea viscosa & $x$ & & & & $x$ & & & & $x$ & \\
\hline Cotoneaster nummularia & $x$ & $x$ & & $x$ & $x$ & & & $x$ & $x$ & $x$ \\
\hline Indigofera heterantha & & $x$ & & $x$ & $x$ & & & $x$ & $x$ & $x$ \\
\hline Myrsine Africana & & $x$ & & $x$ & $x$ & & & $x$ & $x$ & $x$ \\
\hline Debregeasia salicifolia & & $x$ & & $x$ & $x$ & $x$ & $x$ & & $x$ & \\
\hline Anisomeles indica & & $x$ & & & $x$ & $x$ & $x$ & & $x$ & \\
\hline Impatiens bicolor & & $x$ & & $x$ & $x$ & & $x$ & & $x$ & \\
\hline Artemisia maritima & & $x$ & $x$ & $x$ & $x$ & $x$ & & & $x$ & $x$ \\
\hline Indigofera gerardiana & & & $x$ & $x$ & $x$ & $x$ & & & & $x$ \\
\hline
\end{tabular}

L: low altitude $<1000 \mathrm{~m}$.

M: middle altitude 1000-2000 m.

$\mathrm{H}$ : high altitude $>2000 \mathrm{~m}$.

S: sheep.

G: goat.

C: cattle.

B: buffalo.

$y$ : young.

a: adult.

m: milking

pregnant and milking cows and buffaloes. The leaves of Celtis caucasica trees, however, are provided to dry cows and growing stock. Olea cuspidata are considered holy trees because of their mention in the Holy Quran and usually grow in graveyards. The leaves are lopped for feeding sheep and goat in winter. Melia azedarach leaves are provided to milking stock including goats, cattle and buffaloes. 
Robinia pseudoacacia and Ailanthus chinensis are the only exotic trees that are wellsuited to the indigenous feeding system. After being introduced some 50 years ago, Ailanthus chinensis leaves remain unused because of their strong smell. However, after gradual adaptation, the leaves are provided to all animals, particularly milking buffaloes, during the dry summer season. Robinia pseudoacacia were introduced through afforestation projects in the early $1980 \mathrm{~s}$ because of its resistance to hot and dry environments and its rapid growth. However, its contribution to fodder is widely acknowledged by agro-pastoralists of Northern Pakistan. The leaves of indigenous fodder trees and shrubs like Cotoneaster nummularia, Olea cuspidata and Zizyphus jujuba are lopped for feeding the young stock, particularly sheep and goats that are unable to graze on the steep terrain. Similarly Ficus sarmentosa is an indigenous climber and its leaves are lopped for feeding all types of animals particularly by the marginal social segments occupying the steep terrain. Artemisia maritima is an indigenous dwarf shrub available in dry lowlands and uplands, where it serves as a primary browsing source for almost all types of livestock. In moist regions it is however considered a weed.

The leaves of most tree species are a good source of green roughage if they are free from any anti-nutritional factors (Chakraborti et al. 1988). In certain parts of the Indian sub-continent, Zizyphus nummularia, Prosopis cineraria, Prosopis juliflora, Acacia nilotica and Ficus are regularly lopped for ruminant feeding (Sajjad 1991). In the Khyber Pukhtunkhwa ${ }^{\mathrm{b}}$ province, Grewia oppositifolia, Celtis australis, and Leucaena leucocephala leaves are commonly used for livestock feeding (Parveen 1998). Trees are also planted on farmland and farm boundaries (Zomer et al. 2009) as a source of edible fruits, fodder, fuel and shade. Some of the fodder trees are leguminous and in addition to providing fodder, may have additional benefits for soil fertility (Anonymous 2009).

The adaptability of the fodder trees and shrubs vary since some species had a narrow zone of availability whereas others persist within multiple ecological niches. Annual fodder yields vary from 20 to $400 \mathrm{~kg}$ fresh leaves per tree, depending on age, species, lopping patterns and management pattern. Some fodder trees are lopped and fed fresh, whereas others are harvested and piled for winter feeding. Some fodder trees are preferred by farmers for their effects on milk production in terms of quantity and fat content (Devendra 1989).

\section{Social accessibility to fodder trees and shrubs}

Different social groups occupying the study area have unequal access to fodder trees and shrubs. Usually the more nutritious and accessible trees are used by landowners, whereas the remainder are left for the landless herders. Hence, a decreasing availability of fodder trees may affect landless herders first.

There are five main reasons that allow landless herders to have access to the landowners' fodder trees:

1) The tree leaves are less favoured by livestock,

2) The fodder trees grow naturally in remote areas,

3) Other feed resources are abundantly available making tree lopping an unattractive and unnecessary task for landowners,

4) Landowners sell their extra fodder tree leaves to landless herders during winter. 
5) The landowners' herds are mainly composed of cattle, which are very selective, whereas landless pastoralists usually have small ruminants which are less selective.

Considering the latter, Grewia oppositifolia, Zizyphus jujuba and Celtis australis are solely utilized by landowners. Similarly, Quercus incana leaves are more important for landowners in higher elevation areas with long winters. However, at intermediate elevations, these plants are freely available to landless herders for lopping and browsing. Table 3 summarizes the accessibility and use of fodder trees and shrubs by different social groups.

The leaves and pods of Acacia modesta and Acacia nilotica grow in remote areas and hence they mainly feed sheep and goats of the landless herders. Furthermore, the small leaf blade and presence of thorns make them suitable for goat browsing only.

Table 3 use of fodder trees by different social groups of herders

\begin{tabular}{|c|c|c|c|c|c|c|}
\hline \multirow{2}{*}{$\begin{array}{l}\text { Fodder plant } \\
\text { Altitudinal zone }\end{array}$} & \multicolumn{3}{|c|}{ Mobile landless herders } & \multicolumn{3}{|c|}{ Sedentary landowners } \\
\hline & Low & Middle & High & Low & Middle & High \\
\hline \multicolumn{7}{|l|}{ Trees } \\
\hline Ailanthus chinensis & $x$ & $x$ & & $x$ & $x$ & \\
\hline Zizyphus jujube & $x$ & & & $x$ & & \\
\hline Melia azedarach & $x$ & & & $x$ & $x$ & \\
\hline Celtis caucasica & $x$ & $x$ & & $x$ & & \\
\hline Betula utilis & & & $x$ & & & $x$ \\
\hline Corylus avellana & & & $x$ & & & $x$ \\
\hline Robinia pseudoacacia & $x$ & & & & $x$ & \\
\hline Aesculus indica & & $x$ & & & & $x$ \\
\hline Quercus incana & & $x$ & & & & $x$ \\
\hline Quercus dilatata & & $x$ & & & & $x$ \\
\hline Salix tetrasperma & $x$ & $x$ & & & & $x$ \\
\hline Olea cuspidate & $x$ & & & & & \\
\hline Acacia modesta & $x$ & $x$ & & & & \\
\hline Acacia nilotica & $x$ & $x$ & & & & \\
\hline Ficus sarmentosa & $x$ & $x$ & & & & \\
\hline Morus nigra & & $x$ & & & & \\
\hline Diospyros lotus & & & & & $x$ & \\
\hline Morus alba & & & & $x$ & $x$ & \\
\hline Celtis australis & & & & $x$ & & \\
\hline Grewia oppositifolia & & & & $x$ & & \\
\hline \multicolumn{7}{|l|}{ Shrubs } \\
\hline Artemisia maritima & & $x$ & $x$ & & $x$ & $x$ \\
\hline Debregeasia salicifolia & $x$ & $x$ & & & $x$ & \\
\hline Indigofera gerardiana & & & $x$ & & & $x$ \\
\hline Cotoneaster nummularia & $x$ & $x$ & & & & \\
\hline Indigofera heterantha & $x$ & $x$ & & & & \\
\hline Myrsine Africana & $x$ & $x$ & & & & \\
\hline Dodonaea viscosa & $x$ & & & & & \\
\hline Impatiens bicolor & & & & & $x$ & \\
\hline Anisomeles indica & & & & & $x$ & \\
\hline
\end{tabular}

Low altitude $<1000 \mathrm{~m}$. 
Table 4 nutritional aspects of the fodder tree leaves and shrubs available in the study area

\begin{tabular}{|c|c|c|c|c|c|}
\hline Fodder plant & DM [\%] & $\mathrm{CP}[\%]$ & IVDMD [\%] & PIR [gm/4 min] & $\pm \mathrm{SE}^{*}$ \\
\hline \multicolumn{6}{|l|}{ Trees } \\
\hline Ailanthus chinensis & 26.7 & 15.2 & 63.2 & 37.0 & $\pm 3.42^{b}$ \\
\hline Zizyphus jujube & 23.4 & 17.8 & 63.2 & 71.2 & $\pm 14.21^{a}$ \\
\hline Melia azedarach & 21.7 & 12.8 & 62.6 & 36.3 & $\pm 2.63^{b}$ \\
\hline Grewia oppositifolia & 27.3 & 19.9 & 62.2 & 72.8 & $\pm 16.35^{a}$ \\
\hline Corylus avellana & 22.6 & 20.7 & 61.3 & 69.5 & $\pm 14.57^{a}$ \\
\hline Aesculus indica & 28.6 & 18.7 & 60.6 & 67.8 & $\pm 15.12^{a}$ \\
\hline Diospyros lotus & 29.4 & 14.2 & 57.5 & 68.3 & $\pm 15.62^{a}$ \\
\hline Acacia modesta & 23.4 & 17.5 & 55.9 & 41.4 & $\pm 7.23^{b}$ \\
\hline Betula utilis & 28.2 & 19.7 & 54.4 & 70.8 & $\pm 12.17^{a}$ \\
\hline Morus nigra & 27.2 & 14.6 & 54.4 & 69.4 & $\pm 8.23^{\mathrm{a}}$ \\
\hline Acacia nilotica & 22.7 & 18.1 & 54.3 & 43.5 & $\pm 8.44^{b}$ \\
\hline Ficus sarmentosa & 33.4 & 12.4 & 54.3 & 45.5 & $\pm 4.94^{b}$ \\
\hline Salix tetrasperma & 24.8 & 17.4 & 52.7 & 39.8 & $\pm 7.62^{b}$ \\
\hline Robinia pseudoacacia & 23.7 & 11.9 & 52.7 & 40.3 & $\pm 8.61^{b}$ \\
\hline Morus alba & 26.5 & 14.8 & 52.3 & 72.3 & $\pm 11.4^{\mathrm{a}}$ \\
\hline Celtis australis & 23.7 & 10.7 & 49.3 & 69.8 & $\pm 7.66^{\mathrm{a}}$ \\
\hline Olea cuspidate & 36.4 & 11.6 & 46.4 & 38.8 & $\pm 10.76^{b}$ \\
\hline Celtis caucasica & 32.2 & 10.1 & 46.3 & 67.5 & $\pm 20.87^{a}$ \\
\hline Quercus incana & 37.4 & 11.9 & 42.4 & 18.3 & $\pm 2.36^{\mathrm{c}}$ \\
\hline Quercus dilatata & 38.6 & 12.0 & 41.9 & 13.2 & $\pm 1.92^{\mathrm{d}}$ \\
\hline \multicolumn{6}{|l|}{ Shrubs } \\
\hline Impatiens bicolor & 38.1 & 15.6 & 69.7 & 34.0 & $\pm 6.68^{c}$ \\
\hline Cotoneaster nummularia & 36.4 & 19.8 & 63.2 & 70.9 & $\pm 11.39^{a}$ \\
\hline Anisomeles indica & 28.4 & 19.8 & 61.2 & 57.5 & $\pm 8.87^{\mathrm{ab}}$ \\
\hline Debregeasia salicifolia & 33.6 & 18.0 & 58.2 & 67.5 & $\pm 11.00^{\mathrm{a}}$ \\
\hline Indigofera gerardiana & 38.1 & 16.6 & 57.8 & 67.5 & $\pm 15.95^{a}$ \\
\hline Myrsine africana & 36.2 & 23.7 & 57.1 & 53.0 & $\pm 8.47^{\mathrm{bc}}$ \\
\hline Indigofera heterantha & 37.2 & 17.3 & 55.9 & 64.3 & $\pm 9.14^{\mathrm{a}}$ \\
\hline Dodonaea viscosa & 22.2 & 17.3 & 41.9 & 13.5 & $\pm 2.25^{d}$ \\
\hline Artemisia maritima & 31.4 & 13.6 & 41.9 & 16.5 & $\pm 2.31^{d}$ \\
\hline
\end{tabular}

*Each figure represents the mean ( \pm standard error) of four samples. Subscript letters indicate significant differences $(P<0.05)$.

Similarly, the leaves and pods of Robinia pseudoacacia are preferred by sheep and goats. However these are only available inside newly planted forests where the access is being denied to landless herders. Hence, these trees remain widely unavailable for landless herders. The leaves of Olea cuspidata are considered unpalatable and rarely used by the landowners. Therefore, these leaves are widely available to landless herders regardless of whether or not they are planted on landowners' land. Diospyros lotus is mainly planted on cropland boundaries by landowners for its edible fruits. The leaves of these trees are lopped when the scarcity of dry summer is intense and prolonged. However the tree does not bear fruit in the subsequent autumn after lopping. Morus alba and Melia azedarach trees are allowed to grow, or were even planted, on the cropland boundaries. The palatability and tenderness of the leaves make it a good feed for lactating herd members of the landowners. The leaves of all the remaining fodder 
trees are used by both landowners and landless herders, based on accessibility. If landowners have abundant feed resources like fodder crops and crop residues, landless herders may use all the leaves available. In other situations, leaves of trees like Grewia oppositifolia, Zizyphus jujuba and Quercus incana are sold to tenants and landless herders for yearly lopping.

Among the fodder shrubs, Cotoneaster nummularia, Indigofera heterantha and Myrsine africana are considered very palatable and nutritious. However, they are available in the lowland scrubs only and away from the settlements and are thus mainly used by the landless sheep and goats herders. Dodonaea viscosa shrub leaves are occasionally used by landless herders for browsing; however its main use is for fuel. Debregeasia salicifolia are mostly available along the trekking routes and are used by the herds of both landowners and landless herders. Impatiens bicolor and Anisomeles indica are available on the terrace boundaries and are mainly used by landowners' livestock.

\section{Nutritional value of fodder trees and shrubs}

Fodder trees in general have a higher biomass than grass and enough protein to support growth and milk production, especially in the dry season when these species grow extra foliage (Long 1997). Tree foliage is an important source of protein supplement for ruminants fed low protein forages (Long 1997).

Results (Table 4) show that the overall DM of all trees and shrubs vary from 21.7 to 38.6\% (Melia azedarach has the lowest and Quercus dilatata has the highest DM content). Among shrubs, the DM content vary from $22.2 \%$ for Dodonaea viscosa to $38.1 \%$ for Indigofera gerardiana and Impatiens bicolor. The more DM, the less amount of foliage required to fill the rumen of the recipient animal. However, higher DM is usually associated with less tender leaves, less digestibility and thus less energy intake.

On the basis of crude protein, fodder trees and shrubs could be divided into three categories:

1) Species with high protein content (CP > 17\% of DM):

Betula utilis, Corylus avellana, Salix tetrasperma, Aesculus indica, Acacia modesta, Acacia nilotica, Grewia oppositifolia, Zizyphus jujuba among trees and Cotoneaster nummularia, Indigofera heterantha, Anisomeles indica, Myrsine africana, Dodonaea viscosa and Debregeasia salicifolia among shrubs.

2) Species with medium protein content $(14 \%<\mathrm{CP}<16.9 \%$ of DM):

Diospyros lotus, Morus alba, Morus nigra, Ailanthus chinensis, Indigofera gerardiana, and Impatiens bicolor.

3) Species with low protein content $(\mathrm{CP}<14 \%$ of $\mathrm{DM})$ :

Quercus incana, Quercus dilatata, Robinia pseudoacacia, Celtis australis, Celtis caucasica, Olea cuspidata, Ficus tetrasperma, Melia azedarach and Artemisia maritima.

On the basis of digestibility, fodder trees and shrubs could be divided into three categories:

1) Highly digestible fodder trees (more than 60\% IVDMD) include: 
Corylus avellana, Aesculus indica, Ailanthus chinensis, Grewia oppositifolia, Zizyphus jujuba, Melia azedarach, Cotoneaster nummularia, Impatiens bicolor and Anisomeles indica.

2) The fodder tree leaves and shrubs with intermediate digestibility (50-60\% IVDMD) include:

Diospyros lotus, Acacia modesta, Betula utilis, Morus nigra, Acacia nilotica, Ficus sarmentosa, Salix tetrasperma, Robinia pseudoacacia, Morus alba, Debregeasia salicifolia, Indigofera gerardiana, Myrsine Africana, and Indigofera heterantha.

3) The least digestible fodder trees and shrubs (less than 50\% IVDMD) are:

Table 5 Trends in fodder trees and shrub availability in the study area

\begin{tabular}{|c|c|c|c|c|c|c|c|}
\hline Fodder plant & Trend & Common & Dominant & Rare & Cropland boundaries & Forest & Pastures \\
\hline \multicolumn{8}{|l|}{ Trees } \\
\hline Betula utilis & -2 & & & $x$ & & & $x$ \\
\hline Quercus incana & -1 & $x$ & & & & $x$ & \\
\hline Quercus dilatata & -1 & $x$ & & & & $x$ & \\
\hline Acacia nilotica & -1 & $x$ & & & & $x$ & \\
\hline Salix tetrasperma & -1 & $x$ & & & $x$ & $x$ & \\
\hline Ficus sarmentosa & -1 & $x$ & & & $x$ & $x$ & \\
\hline Corylus avellana & -1 & & & $x$ & & $x$ & \\
\hline Aesculus indica & -1 & & & $x$ & $x$ & & \\
\hline Celtis caucasica & -1 & & & $x$ & $x$ & & \\
\hline Diospyros lotus & 0 & $x$ & & & $x$ & & \\
\hline Morus alba & 0 & $x$ & & & $x$ & & \\
\hline Celtis australis & 0 & $x$ & & & $x$ & & \\
\hline Acacia modesta & 0 & $x$ & & & & $x$ & \\
\hline Morus nigra & 0 & $x$ & & & $x$ & $x$ & \\
\hline Olea cuspidate & 0 & $x$ & & & $x$ & $x$ & \\
\hline Zizyphus jujube & 0 & $x$ & & & $x$ & $x$ & \\
\hline Melia azedarach & 0 & $x$ & & & $x$ & $x$ & \\
\hline Robinia pseudoacacia & 0 & $x$ & & & & $x$ & $x$ \\
\hline Grewia oppositifolia & +1 & $x$ & & & $x$ & & \\
\hline Ailanthus chinensis & +2 & & $x$ & & $x$ & $x$ & \\
\hline \multicolumn{8}{|l|}{ Shrubs } \\
\hline Cotoneaster nummularia & -2 & $x$ & & & & $x$ & \\
\hline Myrsine Africana & -2 & $x$ & & & & $x$ & \\
\hline Debregeasia salicifolia & -1 & $x$ & & & $x$ & & \\
\hline Artemisia maritime & -1 & $x$ & & & & $x$ & $x$ \\
\hline Anisomeles indica & -1 & & & $x$ & $x$ & & \\
\hline Indigofera heterantha & 0 & $x$ & & & $x$ & $x$ & \\
\hline Indigofera gerardiana & 0 & $x$ & & & & $x$ & $x$ \\
\hline Impatiens bicolour & 0 & & & $x$ & $x$ & $x$ & \\
\hline Dodonaea viscose & 0 & & $x$ & & $x$ & $x$ & \\
\hline $\begin{array}{l}+1 \text { increasing. } \\
+2 \text { highly increasing. } \\
-1 \text { decreasing. } \\
-2 \text { highly decreasing. } \\
0 \text { no change. }\end{array}$ & & & & & & & \\
\hline
\end{tabular}


Quercus incana, Quercus dilatata, Celtis australis, Celtis caucasica, Olea cuspidata, Dodonaea viscosa, and Artemisia maritima

On the basis of palatability (Potential Intake Rate), fodder trees and shrubs could be divided into three categories:

1) The significantly higher PIR species include:

Betula utilis, Corylus avellana, Aesculus indica, Diospyros lotus, Morus alba, Morus nigra, Celtis australis, Celtis caucasica, Grewia oppositifolia, Zizyphus jujuba, Indigofera heterantha, Indigofera gerardiana and Debregeasia salicifolia.

2) The intermediate PIR species include:

Ailanthus chinensis, Melia azedarach, Acacia modesta, Acacia nilotica, Ficus sarmentosa, Salix tetrasperma, Robinia pseudoacacia, Olea cuspidata, Anisomeles indica, Myrsine Africana, and Quercus incana.

3) The significantly lower PIR species include:

Artemisia maritima, Dodonaea viscosa, and Quercus dilatata.

For the fodder trees Grewia oppositifolia, Zizyphus jujuba, Aesculus indica, Betula utilis and Corylus avellana, the CP, digestibility and PIR are all high, and hence these can be termed fodder trees of exceptionally high nutritional value. The majority of these trees and shrubs are indeed kept and used by landowners' livestock when available in accessible areas. The estimates of $\mathrm{CP}$ in this study are generally in line with those reported in the literature, which vary from 6.9 to $28.8 \%$ of DM (Verma et al. 1982). CP content of Morus alba and Morus nigra (Mulberry) leaves is previously estimated as $19.6 \%$ of DM, which is higher than our estimate (Kundu and Sharma 1988). The Quercus incana tree leaves contain 10.2\% of CP, and Morus alba leaves contain $15.0 \%$ of CP (Gohl 1981). Such variations may be due to different stages of harvesting as younger leaves prior to flowering may contain more protein than mature leaves and leaves after flowering (Nedorizescu 1972). The leaves of Melia azedarach contain 29\% and $23.5 \%$ of CP content at young and mature stages of growth, respectively. Morus alba/nigra leaves contain $23.5 \%$ and $18.2 \% \mathrm{CP}$ at young and mature stages of growth, respectively (Malik and Chughtai 1979). The mean CP value of leguminous browse is $15 \%$, as opposed to $13 \%$ for non-leguminous browse (Jones and Wilson 1987). The nutritional value of some tree species available at higher elevations is much higher than those found at lower elevations. Hence, sampling for propagation should be taken from trees available at higher elevations (Singh et al. 2010). Among introduced tree species Robinia pseudoacacia has a good nutritional value (Corleto et al. 1992).

\section{Trends in availability of indigenous fodder trees and shrubs}

Betula utilis, Corylus avellana, Aesculus indica, Celtis caucasica, Impatiens bicolor and Anisomeles indica are quite rare tree species (Table 5). The most dominant fodder tree species in the study area at lower and middle elevation include Ailanthus chinensis and fodder shrub species at lower elevation include Dodonaea viscosa. Artemisia maritima and Indigofera gerardiana are common shrubs at high elevation with Artemisia maritima being more common in arid to semi-arid areas and Indigofera gerardiana being more common in sub-humid to semi-arid areas. Betula utilis are only available on 
high pastures. Salix tetrasperma, Aesculus indica, Diospyros lotus, Morus alba/nigra, Celtis australis/caucasica, Grewia oppositifolia, Anisomeles indica and Debregeasia salicifolia are primarily available on the cropping field boundaries. The rest of the fodder trees and shrubs are available in the natural forests and scrublands.

Farmers and herders reported that Betula utilis, Cotoneaster nummularia and Myrsine africana are rapidly decreasing. Betula utilis is located in high pastures, in patches usually above tree line and is frequently used as fuel at uplands by landless herders when no other woody species are available, whereas Cotoneaster nummularia and Myrsine africana are the much preferred shrubs available in the lowland scrub areas, and hence are over-utilized due to repeated defoliation and shrinking habitat for the livestock of transhumant herders. Betula utilis is becoming rare, and although the Cotoneaster nummularia and Myrsine africana are still frequent in lowland areas, these species are decreasing rapidly.

Herders reported that the decline of some shrub species in the lowlands is due to an increased density of landless herders in fewer grazing areas following their eviction from closed afforested land. The availability of Salix tetrasperma is declining because it is harvested by landowners to supply the wood industry for furniture and sport items. Quercus incana and Quercus dilatata are mainly harvested by local communities for fuel and is also less available. Other species such as Corylus avellana and Aesculus indica are disappearing as a result of crop extension on upland slopes. These trees usually grow in areas with deep soil and high moisture, contribute to soil retention, but are disliked because of their shade cover, which exclude any other form of cropping beneath. Obviously, such good quality land is preferred for extending crop fields. Similarly, Celtis caucasica, Acacia nilotica, Ficus sarmentosa, Debregeasia salicifolia and Artemisia maritima are decreasing because of the utility of these species as fuel by landowner groups, particularly if found in the vicinity of settlements. The growing cover by Ailanthus chinensis is due to high pollination and germination ability, whereas Grewia oppositifolia is planted at an increasing rate by landowner farmers on the field boundaries for fodder. The population of Dodonaea viscosa remains stable, despite extensive harvesting for its use as fuel in tobacco processing and for household fuel, since it has a high pollination and reproducibility.

\section{Conclusions}

In the traditional farming system of the Himalayan Hindu-Kush region of Northern Pakistan, different types of fodder trees and shrubs are found at different elevations and sites and are used differently by various landowning and landless social segments. The landless herders, who annually rear approximately half a million sheep and goats, are at risk because of decreasing lowland grazing areas and fodder availability along trekking routes and resting sites. This paper demonstrates that indigenous tree and shrub species have a high potential in sustaining a pastoral system in need of alternatives to shrinking grazing areas. The decline in pasture availability is due to afforestation programmes, communal hillside privatization, crop extension and conservation programmes that evict herders from their former grazing areas and trekking routes. The limited fodder availability along the trekking routes in particular triggered early arrival and longer stay at both upland and lowland grazing areas, leading to their overgrazing. 
Planting fodder trees and shrubs in lowlands, along the trekking routes and forest zones below the uplands may make fodder available to landless herders during winter scarcity and transhumance, and can contribute to delayed arrival and reduce stocking pressure at both upland and lowland areas. The distribution pattern of such promotion may include the following.

1) The fodder trees that could be promoted in lowland scrub areas and cropland boundaries are Grewia oppositifolia, Morus alba, Morus nigra, Acacia modesta, Acacia nilotica, Ficus sarmentosa, Zizyphus jujuba, Robinia pseudoacacia and Melia azedarach.

2) The fodder shrubs that could be promoted at lowlands are Cotoneaster nummularia, Indigofera heterantha, Indigofera gerardiana and Myrsine africana.

3) The fodder trees that could be promoted along the trekking routes are Acacia modesta, Acacia nilotica, Zizyphus jujuba, Robinia pseudoacacia and Olea cuspidata.

4) The fodder shrubs that could be promoted along the trekking routes are Debregeasia salicifolia, Indigofera heterantha, Indigofera gerardiana and Myrsine Africana.

5) The fodder trees that could be promoted at the sub-alpine forest zone are Salix tetrasperma, Quercus incana, Corylus avellana and Aesculus indica.

6) The fodder shrub that could be promoted at the sub-alpine forest zone include Indigofera gerardiana

The seedlings of the Grewia oppositifolia, Celtis australis, Morus alba and Zizyphus jujuba can also be provided to landowner farmers for promoting plantation along field boundaries in order to provide fodder, shade and fuel wood or sell it to landless herders during scarcity seasons.

Introducing these trees may substantially contribute to stabilizing social relationships among landowners, sedentary farming tenants, and landless herders who are all competing for fodder resources. Promoting these trees can also greatly enhance food security for communities occupying the mountain valleys in Northern Pakistan and would be efficient substitutes to exotic tree species plantations of large scale afforestation programmes.

\section{Endnotes}

${ }^{a}$ A guesthouse or gathering room for male guests. It is commonly used in Pakistan and is often attached to the house of a wealthy person.

b The former North-West Frontier Province (NWFP)

\section{Acknowledgements}

This research was financed by the Swiss National Science Foundation as a "Joint Research Project" (grant number IZ70Z0 123894) and is partially based on work conducted within the framework of the Swiss National Centre of Competence in Research (NCCR) North-South: Research Partnerships for Mitigating Syndromes of Global Change. Thematic Note 3 Regional Project 15.

\section{Author details}

${ }^{1}$ University of Central Asia, 138-138 A Toktogul Street, 720001 Bishkek, Kyrgyz Republic ²Swiss Agency for Development and Cooperation, Freiburgstrasse 130, 3003 Berne, Switzerland ${ }^{3}$ Centre for Development and Environment, University of Berne, Hallerstrasse 10, 3012 Berne, Switzerland

Authors' contributions

IR collected the socio-economic data and carried out the lab analysis with local partners. All authors contributed to the design of the research and to the manuscript drafting. All authors read and approved the manuscript. 
Received: 20 December 2010 Accepted: 9 May 2011 Published: 9 May 2011

\section{References}

Agriculture Census Organization 2006. Pakistan Census of Livestock, Statistics Division, Government of Pakistan.

Ahmad, H, and Sirajuddin. 1996. 'Ethno-botanical profile of Swat'. Ethnob Appl Concerv NARC, Islamabad 202-211.

Anonymous 2009. 'Hidden benefits of a tree species for African farmers'. CGIAR. 2nd World Congress of Agro-Forestry 23-28 August 2009 Nairobi Kenya.

AOAC 1990. 'Official methods of analysis'. Association of Official Analytical Chemists, Washington, DC.

Atiq-ur-Rehman. 1995. The potential for the use of saltbush in sheep grazing systems during summer and autumn in a Mediterranean climate'. Ph.D. ThesisUniversity of Western Australia.

Boufford, DE, and H Ohba. 1998. Sino-Japanese flora, its characteristics and diversification. The University Museum. The University of Tokyo Bulletin No. 37. www.um.u-tokyo.ac.jp/publish_db/Bulletin/no37/no37000.html. (last accessed on 2905-2010).

Chakraborti, NL, Mandel, and GC Banerjee. 1988. 'Chemical composition of some common tree leaves'. Ind Vet J 65(2): $145-49$.

Corleto, A, E Cazzato, and V Laudadio. 1992. 'Quantitative and qualitative evaluation of tree and-shrubby pasture species in Southern Italy'. Forage Shrubs Breeding and Methodology Meeting, Palermo, 12-13 October 1992.

Devendra, C. 1989. 'Shrubs and tree fodders for farm animals'. Proceedings of a workshop in Denpasar, Indonesia, $24-29$ July 19890ttawa: IDRC Canada.

Etgen, W, and P Reaves. 1978. Dairy Cattle Feeding and Management. John Wiley and Sons, New York.

FAO 2002. 'Crops and drops: making the best use of water for agriculture'. Food and Agriculture Organization of the United Nations, Viale delle Terme di Caracalla, Rome.

Gohl, B. 1981. Tropical feeds. Feed information summaries and nutritive values'. FAO, Animal Health and Production Series No. 12FAO, Rome.

Gomez, K, and A Gomez. 1984. Statistical procedures for Agricultural Research. New York: John Willey and Sons Inc.

Huston, J, and W Pinchak. 1993. 'Range animal nutrition'. In Grazing management: An ecological perspective,ed. Heitschmidt R, Stuth JW . Portland: Timber Press.

Jones, D, and A Wilson. 1987. 'Nutritive quality of forages'. In The Nutrition of Herbivores,ed. Hacker J, Ternouth J . New York: New York Academic Press.

Kenney, P, and J Black. 1984. 'Factors affecting diet selection by sheep. Potential intake rate and acceptability of feed'. Aust J Agric Res 35: 551-63.

Komwihangilo, D, E Goromela, and J Bwire. 1995. 'Indigenous knowledge in utilization of local trees and shrubs for sustainable livestock production in central Tanzania'. Livestock Research for Rural Development 6: 1-7.

Kundu, S, and V Sharma. 1988. 'Chemical composition and in vitro dry matter digestibility of certain tree leaves'. Indian J Anim Nutrition 5: 23-27.

Leede, B, I Rahim, and J Wind. 1999. 'Nomadic grazers and hillside development. A case study in Swat and Buner'. Technical Report 2.9. Amersfoort: Environmental Rehabilitation Project. Malakand Division, WFP (4659)/ERM/PK) 009001.

Long, R. 1997. Tree foliage in ruminant nutrition'. Technical Paper. FAO, Rome.

Malik, M, and M Chughtai. 1979. 'Chemical composition and nutritive value of indigenous feedstuffs'. Lahore: Pakistan Association for the Advancement of Science.

Marten, G, and R Barnes. 1980. 'Prediction of energy digestibility of forages with in vitro rumen fermentation and fungal enzyme systems'. In Standardization of Analytical Methodology for Feeds,ed. Pigden W, Balch C, Graham M . Ottawa: International Development Research Center.

Minson, D. 1987. 'Plant factors affecting intake'. In Ecosystems of the World Managed Grasslands,ed. Snaydon R . Analytical Studies. Amsterdam: Elsevier.

Minson, D. 1990. Forages in Ruminant Nutrition. San Diego: Academic Press.

Nedorizescu, M. 1972. 'Production of some fodder meals from different forest products'. Nutn Abst and Review 44: 21-64.

Parveen, S. 1998. Nutritive evaluation of some fodder tree leaves through in vitro digestibility techniques. Technical Paper, NWFP Agricultural University, Peshawar.

Paterson, R, G Karanja, O Nyaata, I Kariuki, and R Roothaert. 1998. 'A review of tree fodder production and utilization within smallholder agroforestry systems in Kenya'. Agroforestry Systems 41: 181-199.

Rahim, I, and A Viaro. 2002. Swat: An Afghan Society in Pakistan -Urbanization and Changes in a Tribal Environment. Geneva: Institute of Development Studies and Karachi: Karachi City Press Karachi, 1.

Rueff, H, G Kressel, and M Schwartz. 2004. 'Forest fire control and Bedouin pastoralism and Israel's afforested drylands: a cost benefit analysis'. Nomadic Peoples 8: 113-137.

Rueff, H, C Parizot, A Ben Israel, and M Schwartz. 2008. 'Dryland afforestation and poverty alleviation: Bedouin and Palestinian non-timber forest product collectors in contrasting economic environments'. Human Ecology 36: 923-930.

Sajjad, M. 1991. Raising of Buffalo Heifers on Fodder Tree Leaves (Leucocaena leucocephala) and Urea Treated Straw with Green Forage. MSc Thesis University of Agriculture Faisalabad, Pakistan (unpublished).

Samanaya, J. 1996. Evaluation of Feed Resources for the Zero Grazing Dairy Production System in the Fertile Lake Victoria Crescent Zone of Uganda. A Case Study in Jinja Women Heifer Project. MSc. ThesisMakerere University Kampala, Uganda.

Shenk, J, and R Barnes. 1985. 'Forage analysis and its application'. In Forages: The science of Grassland Agriculture,ed. Heath $M$, Barnes R, Metcalfe D. Ames: lowa State University Press.

Singh, B, B Bhatt, and P Prasad. 2010. 'Altitudinal variation in nutritive value of adult-juvenile foliage of Celtis australis L.: A promising fodder tree species of Central Himalaya, India'. Journal of American Science 6: 108-112.

Speedy, A, and P Pugliese. 1992. 'Legume trees and other fodder trees as protein sources for livestock'. Proceedings of the FAO Expert Consultation held at the Malaysian Agricultural Research and Development Institute, Kuala Lumpur, Malaysia, 14-18 October 1991. FAO Animal Production and Health Paper 102, Rome.

Steel, R, and H Torrie. 1982. Principles and procedures of Statistics. New York: Mc Graw-Hill, International Students Edition.

Tilley, J, and R Terry. 1963. 'A two stage technique for in vitro digestion of forage crops'. J Br Grass land Soc 18: 104-111. 
Upreti, C, and B Shresta. 2006. Nutrient Contents of Feed and Fodder in Nepal. Animal Nutrition DivisionNepal Agricultural Research Council, Kathmandu.

Verma, A, B Yadav, K Sampath, and D Roy. 1982. 'Chemical composition of common fodder tree leaves, shrubs and epiphytes in North-East hill region'. Ind J Anim Sci 52: 859-865.

Zomer, R, A Trabucco, R Coe, and F Place. 2009. Trees on Farm: Analysis of Global Extent and Geographical Patterns of Agroforestry'. ICRAF Working Paper. no. 89Nairobi: World Agroforestry Centre.

doi:10.1186/2041-7136-1-2

Cite this article as: Inam-ur-Rahim et al: Indigenous fodder trees can increase grazing accessibility for landless

and mobile pastoralists in northern Pakistan. Pastoralism: Research, Policy and Practice 2011 1:2.

Submit your manuscript to a SpringerOpen ${ }^{\odot}$ journal and benefit from:

- Convenient online submission

- Rigorous peer review

- Immediate publication on acceptance

- Open access: articles freely available online

- High visibility within the field

- Retaining the copyright to your article

Submit your next manuscript at $\gg$ springeropen.com 